Research Paper

\title{
A Review of Theory on Forestry Politics in New Order Indonesia
}

\author{
Anne Cullen \\ American University in the Emirates \\ United Arab Emirates \\ E-mail: anne.cullen@aue.ae
}

\section{About the author}

Dr. Anne Cullen is Associate Professor/Associate Dean of the College of Mass Media and Communication at the American University in the Emirates in Dubai. She spent several years living in Indonesia establishing close contacts in the Jakarta business, political and academic communities and has participated in a World Bank-funded project to retrain mid-career diplomats from the Vietnamese Ministry of Foreign Affairs in Vietnam. Her research interests focus on business and political relationships in Asia, and improving international education. 


\section{Abstract}

Political control was an enduring characteristic in New Order Indonesia. From the time following the 1965 coup, through to the brutal end of the New Order era in 1998, President Soeharto and his New Order government first tamed and then controlled Indonesian society. Because of this overarching political strategy, orthodox political analysis during that time assumes a de-politicised amorphous civil society that precludes successful constituency politics. This paper presents a review of that literature and then moves on to present evidence of the existence and successful engagement of constituencies in the policy making processes.

Keywords: Indonesia, Forestry, Politics, Constituency, NGOs, Pluralism

\section{Introduction}

As environmental awareness grew in the 1980s and 1990s, an increasing amount of literature focused on the environment in Indonesia. Historical interpretations of environmental politics during Soeharto's New Order Indonesia covered issues such as the pollution of the earth and air to the proliferation of golf courses (Amsyari, 1992; McBeth, 1994; SKEPHI, 1992). Much of this attention was the result of Indonesia's Outer Islands supporting the largest remaining area in Asia of tropical rainforest. Responding to the escalating rates of deforestation analysts tended to lose sight of the political terrain in favour of cause-and-effect analysis. Very little attention was paid to the political motivations of, or the relationships between, the environmental NGOs (Non-Government Organisations), the political and bureaucratic elite, or the state. Even less attention was paid to the theoretical assumptions informing the political analysts and the implications this has on their findings.

The following paper undertakes a reflective survey the analytical work dominating analysis in the New Order. It uses source materials from the period to facilitate an immersion into the analyses to understand the impact of dominance-as-orthodoxy. Such orthodoxy in the case of forestry politics of the New Order led to an invisibility of constituency political mechanisms and a limited understanding of the form of pluralism evident. Ultimately the paper presents a case-study and theoretical framework, targeted Pluralism that builds on existing theoretical work to normalise the role of NGOs influencing state policies using targeted strategies.

The paper aims to show how constituencies, aware of the monolithic nature of the state, used targeting mechanisms to press their political will on policy in a pre-electronic/social media era. It will argue that in many respects the NGOs were the product of the authoritarian government, and existed because of it.

\section{Being Theoretical}

For most analysts, the New Order state was seen as utterly dominant in its relationship with society. Society had little ability to check the state's dominance because of cultural, political and institutional constraints. 
Society was seen as subordinate, bereft of political activity, excluded from policy making processes, and so largely ignored. At their most strident, analyses understood the politics as a state-qua-state framework. But on the whole, the analysts of environmental politics in New Order Indonesia held the interpretive cluster of patrimonialism and bureaucratic polity as models. Pluralism models were evident, but not dominant. The following review surveys this field of work.

\section{State-Qua-State}

The development process and who controls it was central to Raymond Bryant's analysis where all conflicts were about power and who controlled forest land-use decision-making (Bryant, 1994, p. 13). Bryant explained a "dynamic of control and resistance" where state (for a government perspective, see Daryadi, 1994) and society opposed one another (Bryant calls on Peluso's work on control and resistance. See Peluso, 1992 and N. L. Peluso, 1993). Bryant's use of political ecology evaluated the state-society nexus according to interpretive terminology such as, 'control and resistance', 'wealth and poverty', and 'environment and development', amplifying the differences. But ultimately, political ecology was about power and who had it.

Robert Repetto, incorporated bureaucracy as a fundamental cause of deforestation: governments were "aggravating the losses of the forests under the stewardship through mistaken policies" (R. Repetto, 1988, p.1). Isolated bureaucrats worked in elite echelons, susceptible to patrimonialism and served the demand for rapid development (pp.45-46). Repetto portrayed the international interests in forestry as an insular group, unaffected by constituency politics. In essence, this strident, narrow state-centred interpretation which damned the fundamentals of policy-making procedures must, by incorporation, damn any constituency involved in that process.

\section{The Patrimonial and Bureaucratic Polity State}

Here the political elite excluded society and relied on traditional forms of leadership; whereby material rewards were bestowed to favoured political and bureaucratic groups. The cost of this largesse was borne by society. Analysis of political conflict was confined to the cliques within the political and bureaucratic elite, as they sought a larger percentage of the rewards for loyal service to the ruler (MacIntyre, 1997, p. 7; Jackson, 1978). Analysis maintained the state in opposition to NGOs. This model of patrimonialism highlighted the strong relationships between Soeharto's family and Chinese-Indonesian industrialists who became part of the elite.

NGOs did have a voice when it buried criticism in analysis recalling the forestry legal framework first, and then the failings of the patrimonialist (A fine example of this is, SKEPHI, 1989; 1993; 1992). The industrialists were seen as the culprits- not the state or its policies. Direct criticism of the state and its actions was avoided; a serious consideration in a state where sedition charges were possible and culture ensured public criticism of any individual was frowned upon.

Gale Dixon agreed and added "many other companies have Indonesian partners, who $\cdots$ are both government agencies and private corporations as well as some individuals" (Dixon, 1974). Richard Robison 
discovered broader patrimonial (military) tendencies in the sector (Robison, 1986, p. 256). Michael Vatikiotis accused nepotism when the government bestowed economic largesse upon supporters and financiers, "many of whom had been granted forestry concessions in return for political favours" (Robison, 1986, p. 44). Philip Hurst concurred: "There is little doubt that political favours were involved in the allocation of many timber concessions" (Hurst, 1990, p. 16). Western political analysts held little doubt about patrimonial links.

\section{Pessimistic Bureaucratic Polity}

Dauvergne (1993-1994, p. 517) presented a pessimistic essay where the state was portrayed as corrupt, converting natural resources into cash, its bureaucracy dominated by profit seeking, and all protected by the military. People were the pawns of the state. Patrimonialism was a contributory factor to deforestation as

policy was made according to "vested interests which benefit from and which encourage and support activity which leads to deforestation" (p. 498).

Solutions to deforestation as proposed by environmentalists, developmentalists and policy analysts were ineffective "without corresponding changes to the attitudes and practices of the Indonesian elite." Dauvergne's pessimistic analysis offers limited insight into the politics of deforestation in Indonesia.

\section{The Victimising State}

Joan Hardjono (1991, p. 8), presented analysis which revisited the theme of access and control over resources. Control over the resources, was taken from the people and sited firmly in the hands of the state: "at one time the local people had free access to these resources but now they are increasingly excluded or else obliged to work on unfavourable terms as exploitation rights are given to urban-based companies" (p. 9). The people were seen as victims and policies unjustly discriminated with displacement, diminished incomes, and polluted environments (p. 12).

Mark Poffenberger (1990, p. 16) also suggested that the population were victims controlled by government; a condition with a two century history and little opportunity for change. The concentration of control of resources served to isolate forest communities not only from tribal forests and lands, but also from the political right to control forest resources.

Central to Poffenberger's argument was the notion that state sought to increase control by increasing their forested-land holdings and conflict arose when the bureaucrats argued over the allocation and control. Having gained control agencies were unlikely to forfeit the land or power it brought. Consequently policy was not determined by notions of equity or populism, but rather by the level of economic or political clout of specific groups. By denying the political role of constituency groups, analysts exposed the reader to only part of the political terrain of the forestry sector. 


\section{More Pluralistic Models}

Authors in this group shared the underlying conviction of the previous authors, that the state remained the primary political actor. But the structures of the state and its bureaucracy were more flexible than in previous analysis. Constituencies were afforded political space, although the scope of that space varied with individual authors.

\section{The Limited Pluralist State}

David Potter encouraged a limited pluralism as his research centred on NGO ability to change "policies in order to slow down the forest destruction currently going on" (Potter, 1994, p. 1), NGOs that worked "to influence the policies on tropical forests of other organisations like government departments and economic enterprises" (p.8). Potter stopped short of unequivocal support for pluralism, because emerging constituencies (NGOs) were less influential than more powerful constituencies. Potter (p.9) asserted that in Asian contexts, "state actors frequently decide which groups are allowed into policy process, and which other groups are definitely out." For Indonesia forestry sector politics specifically, Potter called for a political model which was less open than conventional pluralism - a constrained pluralism.

Bernard Eccleston (1994) accepted the right of society, especially NGOs, to be political. He found that the level of democracy influenced the ability of the NGOs to influence and act. NGOs advocated by exploiting the differences between the 'centres of power' (Schmitter and Lehmbruch, 1979; Bourchier and Legge, 1994): identifying sympathetic bureaucrats and personal relationships was crucial which provided "alternative points of leverage for NGO influence" (p. 2). Theoretically, identifying alliances of NGOs with bureaucrats was a substantial shift from previous analysts.

\section{The Inclusionary State}

Robert Cribb (1988) laid forth a maturing plurality in Indonesian politics, both in the state and constituencies, which facilitated a complex communication and due to three factors:

First...the economic and social costs of environmental degradation are becoming clearer and governments are adjusting their policies pragmatically. Second...rising affluence in some sections of Third World societies has generated the characteristically middle class concern for the environment which is found in the West, and governments are sufficiently responsive to public opinion to modify their policies. A third reason, less commonly recognised, is that environmental issues have become a convenient vehicle for other political struggles. (Cribb, p. 2)

Cribb acknowledged the patrimonial 1960s and 1970s, and agreed that capitalist interests "emerged under the close protection and domination of local bureaucracies, feeding on graft and corruption" (p. 27). The emergence of environmental NGOs signaled a change in the society's, and state's, reaction to environmental 
problems and political relationships. According to Cribb, on the one hand, the state used environmental issues to bolster their authoritarian power and social control, but not linked to increased. The New Order asserted a high level of regulation to maintain an obedient society, and environmental issues were one avenue for the state to tighten control.

\section{Is that all there is?}

Up to this point the dominant views agreed that the state was patrimonial and policy was the business of bureaucrats insulated from constituency interests. The policy-making processes were the product of the state either for the state's own ends, or responding at the demands of the political and economic elite, as well as timber industrialists with strong patrimonial links. Consideration of constituencies was constrained by three factors: first, by the political and economic power of the state, and which inhibited NGOs; second, the cultural barrier which demanded criticism of the state be done privately; third, the institutional barriers such as corporatist frameworks of organisation between the state and NGOs. In short, there remained a residual tension between the state and society.

These conclusions are not startling given the then prevailing interpretations of Indonesian politics in general: analysis tended to be state-centred and societal interests were not seriously considered as influencing the policy process. At that time, environmental politics were a relatively new dimension to political science, and so understandably the theorists drew on existing interpretations of the Indonesian state and applied them to environmental issues.

\section{Restricted Pluralism}

R. W. Liddle (1987) and his model of Restricted Pluralism provided an understanding how constituencies during the New Order were able to operate in the domestic political domain to effect policy favourable to their demands. Liddle highlighted six brief agricultural case-studies as evidence of "direct participation in politics by more or less organised interest groups" (p. 143). Through his case-studies, Liddle showed that there was more political activity in Indonesia than previously thought: there was a 'restricted pluralism'.

Liddle's less orthodox view proposed to find the political mechanisms and factors "that may operate to the advantage of economically and politically weak groups" (p. 129), without suggesting a model of politics which is society-driven. Liddle agreed with the strength of the state: "but believe it is possible to find variables that, while a part of the system, nonetheless work or can be turned against its basic tendency to concentrate wealth and power" (p.129). The variables were separated into two categories: first the constituent groups which identify those people who were affected by a policy, and, second, the strategies the groups employed to exert their influence on the policy making process. For the forestry sector, constituencies were across three categories (see Figure 1) thereby blurring any distinct boundaries and broadens the Liddle model.

As Liddle identified, the constituencies needed strategies to achieve influence. Liddle identified four such strategies:

Journal of Management and Training for Industries, Vol.2, No.2, 2015 


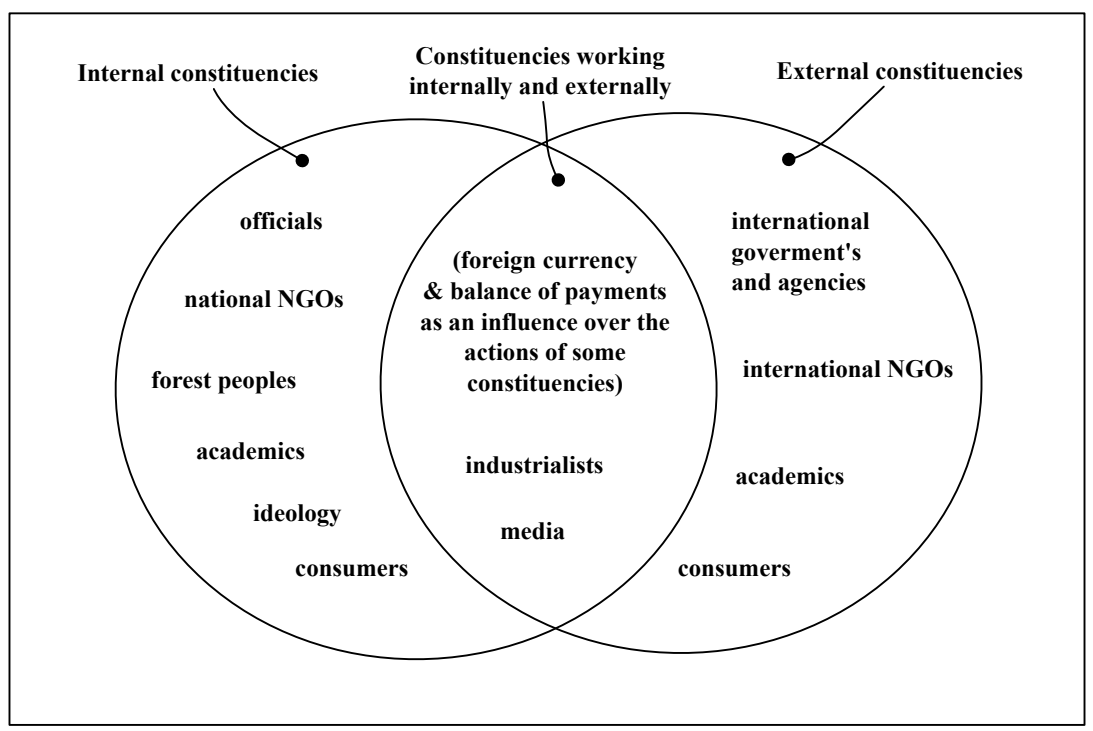

Fig. 1 The constituency and role of NGO's

\section{Anticipated Participation (AP)}

AP means the "reactions to what officials anticipate to be the demands of particular constituencies because they recognise[d] the actual or potential power of the constituency's political and economic resources" (p. 129). In the forestry, the timber industry pursued rent-seeking activities and was led by powerful political allies of the state, who on occasion appeared to act as part of the bureaucracy. Consequently their interaction with the state apparatus was a pluralist activity. The industrialists experienced little difficulty in having their demands be known and implemented. Access to the Minister was assured for Bob Hasan as President of ISA (Industri Sawmillers Association - Industry Sawmillers Association), APKINDO (Associasi Panel Kayu Lapis Indonesia - Wood Panel Association of Indonesia) and other trade related organisations. In essence, the financial resources of the industrialists, and ties to the Presidential palace "equipped them with more power than most cabinet ministers" (Vatikiotis, 1993, p. 14). As a result the state and its bureaucracy anticipated this constituency's participation in the policy.

Environmental NGOs, worked harder to be heard and developed personal ties with bureaucrats. As a result, the bureaucrats anticipated issue-specific political problems from policy decisions. However, this political strategy of association was not straightforward and was dependent on personalities. For example, the clash of personalities between the Minister Harahap (1998-1993) and NGO leaders meant the two did not advance the environmental message (Salim, 1995). However, subsequent Minister Soeryohadikoesoemo negotiated a more workable relationship. Personal links facilitated political patronage and indicated that corporatism control over the NGOs was more porous than thought possible, and suggested a form of (targeted) pluralism. 


\section{Bureaucratic Identification (BI)}

BI suggested that constituents influence top policy-makers largely by acknowledging their status, then respectfully making demands within the terms of this relationship. The demand can flow both ways, when bureaucrats needed "to mobilize external support for internal battles" (Liddle, pp. 129-130). BI also relied on the beliefs of the bureaucrat (at least superficially) corresponding with those of the interest group.

BI could lead to outright capture of an agency by its clientele but Liddle thought it unlikely in Indonesia because of the relative power of the state. However within the forestry sector limited capture occurred because of the relationship between the Ministry and timber business' constituency. According to Hendro Prastowo, Deputy Executive President APHI (Asosiasi Pengusaha Hutan Indonesia - The Association of Indonesian Forestry), APHI worked so closely with the Ministry that all policy was decided together, and, "we only see policy we have agreed to" (Prastowo, 1994).

\section{Allies of Convenience $(\mathrm{AoC})$}

AoC defines the bureaucratic and interest group relationship as being dependent upon the "linking of the demands of a disadvantaged to those of a privileged group because of a coincidental congruence of goals or interests" (Liddle, p. 130). In other words, constituencies benefited from policy which directly addressed their needs, even though the policy was drafted as the result of internal political manoeuvring. For example, forest peoples were more likely to attain basic rights with Soeryohadikoesoemo as he tried to redress the domination of forestry by the timber tycoons and responded to the political platform of the New Order to encourage pribumi (indigenous) businessmen (Warning to Loggers, 1993). The advantage to the forest constituencies, was that the Ministry bureaucrats felt empowered to implement policy unpopular with the tycoons, and uphold their 'moral' obligations to the people. Empowerment occurred as the Ministry handed more responsibility to the people in the management and protection of the resource (social forestry enrichment programs), eroding the trend of concessionaires as forestry managers (Cohen, 1994; A Bitter-sweet Existence, 1993).

\section{Ideological Tradition (IT)}

IT referred mainly a populist ideological tradition: Officials listened "more closely to the demands of certain groups because they have internalised an ideology that puts the needs of "the people" first and because the ideology defines the universe of political discourse in which all Indonesians live" (Liddle, p. 144). In the forestry sector the state and its bureaucracy responded to the ideologies of sustainable forestry and development and sometimes in conflict with the predicted policy pressure from the timber business constituency. Ministerial pronouncements supported the ideology of sustainable development by informing industry and public of their intent to enforce policies designed to ensure sustainable practices, and by educating the general public about the role of the forestry sector in Repelita (National Five Year Development Plans) (Number of Negligent Holders of Forest Concessions Declines, 1991). 
On occasion, issues arose which demonstrated the dominance of this ideology against the political forces which would have appeared to carry more weight. In 1991 PT Barito Pacific Timber Group (BPT - controlled by Pangestu) breached regulations by felling logs illegally on state forests and competing concessions. The Ministry fined BPT (Tree Felling on State Forest May Land Barito in Court, 1991; Barito's Rejection to Pay Rp.11.1b Fine Questioned, 1992). Ultimately, no fines were upheld due to a technicality and confusion regarding actual boundaries of BPT's concession (Pemerintah tak Berhak Kenakan Sanksi kepada PT Barito Pacific, 1991). However, that the Ministry (under Soeryohadikoesoemo) was prepared to challenge the largest forestry concession conglomerate shows that the forestry tycoons were being subtly limited through the use of symbols of IT.

Ideology, in general, is the glue for state and society relations and demanded consideration of constituencies in policy making. Ultimately, however, ideologies are about power, and how the state maintains legitimacy by constantly reinforcing a value-system (Concession Holders Urged to Help Nomadic Farmers, 1991; Hardoyo, 1992) through 'ideological state apparatuses' as social organisations (Althusser, 1971, pp. 142-143). For forestry policy, the state repeatedly confirmed that forests were State owned (The Basic Forestry Law), to be developed to conserve the natural resources (See 1967 National Day Address) for the long term use of the resources (Constitution of 1945, Article 33) potential economic benefits, while maintaining the nation's environmental quality (Hutabarat and Ganie, 1991, p.6). Before, Dutch colonial legislation legitimatized state control over Indonesian natural resources. Althusser's 'ideological state apparatuses' played a significant political role by informing individuals on how to think about issues (Ministry of Forestry, Government of Indonesia, \& Food \& Agriculture Organisation, 1990)

Ideology held the potential to undermine state policy (Hasjurul Threatens Slash-and-burn Farmers in Sumatra, 1991) if its use was shown to be rhetoric (Suharyanto, 1994, p. 30; Foreign Forest Concessions Reminded of Mandatory Divestment, 1991). Environmental activists pressed their demands that the state include the concept of sustainable development in all policy. Failure to do so provided the opportunity for the environmental NGOs to turn onto the state and raise questions in the collective public mind as to why the state forfeited its traditional role as custodian.

\section{Was Restricted Pluralism enough?}

This paper proposes that the notion of pluralism held by Liddle was largely correct - but by investigating an economic sector such as forestry, we identify other power-political strategies used by activists to exert their demands on the ruling elite in Jakarta. Identification of additional strategies (international patronage, flexible participation, and BINGO involvement) revealed political pluralism that was not so much 'restricted' as it was 'targeted'. 


\section{Targeted Pluralism}

Targeted Pluralism presents a model that identifies constituency political activity in the New Order that was far more visible. Indeed, the 'wins' attributed to the environmental NGOs relied on a high national and international profile of the activists' undertakings and the visibility of the timber corporation acts.

Targeted Pluralism, agrees that the 'influence' society-based political actors exerted on the decisionmaking was dependent upon the perceptions, beliefs and interests of insiders. Not able to work politically in their own right, activists needed to influence key policy makers. The wins of the environmental NGOs showed that the Indonesian polity was not monolithic: policy was influenced. The acts of influence included all the Liddle's mechanisms along with other 'targeted' means. Targeted Pluralism means, simply, that the activists targeted their advocacy by using mechanisms that extend restricted pluralism, and that deserve to be recognised in their own right. For the forestry sector, the additional mechanisms were, (a) international patronage, (b) flexible participation, and (c) BINGO involvement. To exemplify how these mechanisms worked, this paper offers a case-study, the Astra-Scott campaign (ASC), to best highlight the interplay of all mechanisms in Targeted Pluralism of the New Order period (Cullen, 1998; Aditjondro, 1988).

\section{Case Study: the Astra Scott Campaign (ASC) (1988-1989)}

On 5 December 1988, a partnership between the Astra Corporation (Indonesia) and Scott Paper Company (USA) (SPC) announced a proposed integrated forestry industry project involving an area of 800,000 hectares in Iran Jaya for a 35 year period. The partners made the decision to announce the substantial Indonesian-US joint venture in the Malaysian press; a low-key launch strategy designed to avoid activist backlash. Neither partner had a pristine corporate record: SPC had a mixed environmental history and Astra was the then second largest Indonesian conglomerate with political favouritism.

Analysis of the ASC case provides a means for understanding aspects of the then political processes in Indonesia as societal and state groups worked, and clashed, with each other as they pursued their contrary aims. The ASC case captures the moment in time when Indonesian activists professionalized their strategies and actions viv-a-vis other constituencies deemed to be counter to environmental protection and best-practice. The ASC relied heavily on international NGOs and their ability to apply pressure to the SPC in the United States. This spread the campaign across two broad fronts; another first for Indonesia. The international NGOs applied economic pressure on SPC by pursing product boycotts and letter writing campaigns. The national NGOs' campaign concentrated on forging relationships with bureaucrats and ASC management to secure the best outcomes for the people and environment. ASC offered an opportunity for the activists to reverse policy, elicit a measure of pluralism, and/or to effect changes that were for the betterment of particular communities specifically or for the forestry sector; thereby avoiding advocacy for advocacy's sake.

The ASC campaign saw new forms of state and society relations at a time of rapid political change; 
the NGOs challenged their depoliticisation and engaged in professionalized relationships with the state. Protagonists forged relationships with bureaucrats as allies of convenience, utilized bureaucratic identification to exploit government perception of anticipated participation by constituencies wielding political and/or economic power, and deployed populist and sustainable-development ideological rhetoric to support their position.

\section{Targeted Pluralism and International Patronage (IP)}

International Patronage bolstered domestic advocacy. IP took many forms, but fell across three main categories: financial, networking and academic validation. No matter how the mechanisms manifested, forging international patrons and allies was crucial for national and international recognition, and provided legitimacy for the domestic actions of the Jakarta-based NGOs involved in ASC.

Activists specifically targeted individuals and organizations in the international polity that would best champion their advocacy. For example, one of the first NGOs contacted was Multinational Monitor which monitors multi-national corporations, such as SPC. It was requested to double-check the details of the project. Then, NGO-identity Aditjondro made contact with AFSC (The American Friends Service Committee), the main Quakers overseas support agency, through personal contacts and a formal letter of 5 May 1988. The letter proved to one of the most targeted contacts of the campaign: one of the AFSC ex-treasurers, Oliver Rogers, was also once a SPC Vice President. AFSC indicated that they would approach Rogers for his assistance in discussions with SPC, and if Rogers were agreeable, incorporate him in their campaign. He was, and AFSC was able to facilitate elite level access to the SPC corporate hierarchy. At the same time, the domestic NGOs targeted international media to garner broader state and non-state, national and international, support. Financial IP support from international sources eventuated as the Jakarta NGOs were plugged into international NGO networks, a hitherto untapped resource: a highly successful strategy. IP highlights links formed, across borders, to establish and exploit like-minded organization networking and academic validation and potential financial patronage; all of which had one intended outcome - to facilitate transnational pressure to affect policy changes.

Academic validation IP also occurred. A report written by Pathay and Aditjondro at the beginning of the campaign qualified as academic support of the campaign, but written in Bahasa Indonesia it remained essentially a domestic report (Pathay \& Aditjondro, 1987). The academic IP component truly took hold only when peers at Cornell lent their support to the campaign. Reports written by international academics had power to support action in an environmental campaign - and act as a clear example of academic patronage.

\section{Targeted Pluralism and BINGOs Participation (BP)}

BP emerged as a telling mechanism as a direct result of the Pathay and Aditjondro paper: the report had been authored as part of the research activities of a smaller regional NGO, YPMD-Irja (Yayasan Pengembangan Masyarakat Desa - The Irian Jaya Rural Community Development Foundation) which lacked the political space, contacts or strength to withstand any political backlash from opening what a sensitive do- 
mestic issue. Larger Jakarta NGOs, such as WALHI and SKEPHI, did have suffice patronage. (YPMD-Irja was involved in community development for the remote areas of Irian Jaya. It networked with other NGOs over Irian Jaya, giving their programs depth and width. It sought to improve village heads' understanding of the EIA, and worked with WALHI and YLBHI to do so. For explanation of YPMD-Irja and the EIA Regulation (no. 29), see Eldridge 1995 (pp. 137-140). These NGOs were BINGOs (big NGOs) to differentiate their capacity and size to the smaller and regional NGOs. Indonesian official classifications echo the anlaysis: LPSM (Lembaga Pengembangan Swadaya Masyarakat- Institute for Promoting Self-Reliant Community Development Organization) and LSM (Lembaga Swadaya Masyarakat- Self-Reliant Community Organization) immediately identified the organisation as a large umbrella (and predominantly Jakarta-based) NGO or a smaller regional organisation respectively.

The ASC case presents the first evidence of BINGO mechanisms working on the international front of advocacy. The international BINGOs took the messages of the Indonesian NGOs to the international media to deepen the campaign. The international BINGOs took the issues to all readers of the New York Times in an advertisement designed and placed to inform and attract the support of the general community. The advertisement showed portraits of eight men, who, the caption declared, "will decide the fate of your children." (The advertisement may be found in the New York Times, 8 August 1989. A reproduction of the advertisement graphic and script was reproduced as SKEPHI, "Anti-Scott Campaign Gains Momentum", Setiakawan, No. 2, September-October, 1989, pp.16-18. The men were, Phillip Lippincott, Chief Executive Officer of SPC, Barber Conable, President of the World Bank, Nicholas F. Brady, Secretary of Treasury, US Treasury Department, Pesidente Jose Sarney, President of Brazil, George Bush, President of the USA, Yab Datuk Patinggi Haji Abdul Taib Mahmud, Chief Minister of Resources Planning, Malaysia, Shinroku Morohashi, President and Director Mitsubishi, and T. Marshall Hahn Jr., Chairman COE Georgia Pacific Co., USA.) The script of the advertisement informed readers of SPC actions in Irian Jaya, and was a call to action to readers of The New York Times, and beyond.

\section{Targeted Pluralism and Flexible Participation (FP)}

FP means: the environmental NGOs ability to operate and advocate outside the existing Indonesian partypolitical system. By existing outside of the formal political processes, NGOs were more autonomous. To be sure, the NGOs were potentially restrained by ORMAS (1986) regulations designed to reinforce corporatist power relationships between state and society. The aim of ORMAS was to consolidate state control over all social organisations by subjecting Board composition to state approval, and reserving the right of the government to provide guidance in the form of general advice, recommendations, directions, instructions, consultation, education, and training and information. ORMAS was also designed to centralise the institution of Pancasila in Indonesian life, thereby gaining ideological control. According to ORMAS, all social organisations were required to register with all levels of the government, and the three relevant levels of Minister of Home Affairs, Governor of the Province and Mayor of Kabupaten. ORMAS also held the right to disband any organisation proven to endanger social order, subversive in their actions, or a general threat to stability. 
By 1985, the MoF (1987) considered the constituency and role of NGO's to be the following :

- Indonesian Timber Community

- Indonesian Wood Panel Producer's Association

- Indonesian Sawmillers Association

- Indonesian Rattan Manufacturers Association

- Pulp and Paper Producers Association

- Wood Preservation Association

- Society of Indonesian Forestry

- Society of Indonesian Boy Scout

- Armed Forces Reforestation

There were three basic groups; trade, military and Boy Scouts. There was no mention of environmental NGOs, despite their cooperative efforts. Remaining outside the political party processes also allowed the NGOs to pursue actions, for example, within the legal system.

As Agus Ramansara (1995) noted, "there is no point in protesting for the sake of protesting...the main strategy to begin a campaign is to gather information and make rational decisions". The rational decision was based on NGOs' expectations of which bureaucrats would sympathise with NGOs' either at a personal level, because of an internal political tussle where external support was desired, or as a reflection of internalised ideologies. Also, the decision to begin a campaign would be swayed by the availability of government information (analytical and statistical) supporting the NGOs' campaign. NGOs made rational decisions about the susceptibility of issues to their advocacy. For an environmental campaign to be successful, it needed to be presented on the national political stage by a recognised Jakarta BINGO. This would appear to be a self-evident truth: the larger the NGO, the greater its constituency, and thus its influence. BINGOs often accepted the responsibility to act on the behalf of the regional NGOs and individuals.

The Astra-Scott campaign sought to save the lifestyle and ecological base of residents in the Merauke region. BINGOs rallied national and international environmental constituencies by placing on the national agenda what was essentially a local issue. For example, BINGO Bina Swadaya was instrumental in an embedded campaign which sought to raise incomes and sustain the ecological base of local Iran rural areas, and acted as the national coordinator for the smaller NGOs while the Ford Foundation assisted in keeping the issue at a national level and facilitated the cooperative efforts.

Other NGO involvement included the environmental focused WALHI and SKEPHI, which had negotiated their primacy as the environmental BINGO umbrella organisations. However, the creation of these umbrellaorganisations served to undermine the primary intention of the state; to control the constituencies. BINGO umbrella organisations rallied their networks, government contacts and financial supporters, to create environmental supra-constituencies. The constituency potential of the BINGOs became worldwide, thus creating a constituency with serious economic and political demands which needed to be heard by government.

This form of national and international interdependence was evident in the SPC case. By targeting bureaucrats who held the potential to be allies of convenience, NGO linked their demands to the goals 
or interests of government officials. In this matter they identified two willing allies. The first was Emil Salim, Minister of Population and the Environment, and technocrat, who had a strong relationship with the BINGOs and was universally viewed as the NGO champion. Salim was known to hold a strong position against open confrontation with SPC, as he thought that his Ministry would be able to control the actions of the US corporation through EIA, yet he maintained a delicate position by supporting the activists.

The other prominent government representative targeted was Irian Jaya's Governor, Barnabas Suebu. Suebu, who took office in April 1988, at much the same time as the ASC campaign began in earnest, was the youngest of all Indonesia's governors and pro-development. At first Suebu did not look like a likely ally. However, Suebu had attended school with the BINGO activites (Ramansara, 1995). Their shared experiences formed a mutual respect for each other, despite their opposite political ambitions. Suebu identified with Ramansara for his own ideological and political reasons and thus championed the interests of the BINGOs in the SPC case. However this personal connection does not adequately explain why Suebu entered into dialogue with the environmental groups. On the one hand Suebu needed to protect his fledgling political career, and consequently his ambitions would have been better served by remaining within the development framework of state policy. On the other hand, as was revealed since the ASC case, Suebu was also motivated by personal financial interests; a giant project in Mamberamo region, where his daughter was to be one of the commissioners. He also believed that if the forests were to be depleted in the interests of national development, then better national companies rather than overseas interests execute the deforestation. Suebu's nationalist identity in this case assisted his decision to support the NGOs in opposing the technocrat-type (free-market, open-door) economic aspects of the ASC project, and pitted him against the (technocratic) supporters within the bureaucracy. In other words, Suebu initially allied with the Indonesian NGOs to mobilize external support for internal political needs.

BINGOs concurrently believed it was important to find a contact in SPC, an ally of convenience, so that they were not seen to be railing against the company without having entered into a dialogue. The AFSC link to Oliver Rogers provided the networking required and exemplifies the nature of FP.

The advocacy intricacies of the SPC case are far too complex to fully discuss here. However the positive effects of Target Pluralism is best witnessed by the Press Release from SPC dated 13 October 1989. In this Press Release, SPC advised P.T. Astra, the GoI, and the international media and observers that it intended to withdraw from the ASC project in Irian Jaya. The Press Release was oblique as to the reasons. What we do know is that this decision came after: the international patronage of academics and activists; the New York Times (and others) utilized as an information conduit by the protestors and the forestry tycoons; the 6,000 concerned citizen letters of protest received by SPC, the global threatened and anticipated international boycott of SPC products; the exploitation of internal bureaucratic power struggles in Jakarta; the flexible participation of BINGOs across the Indonesian polity; the challenge for the state to uphold the national ideology that binds the right of Indonesians to protection the national environment, and, bureaucrats to uphold the national legal tenets. 


\section{Conclusion}

This paper has concentrated on bringing together and finding the impact of the political models that dictated analysis of the forestry sector in New Order Indonesia evaluated the possibility for policy reform by constituencies. It argued for analysis that acknowledged micro-issue wins of the activists.

Political analysts at that time contended that politics, and the notion of power in Indonesia, rests upon its authoritarian nature. A plausible conclusion is that political scientists had not noted the role of constituencies due to their concentration on the bureaucratic and elite-level politics, or as MacIntyre (p.17) noted, "it is difficult to talk of societal inputs into policy if one has little knowledge of the means by which this might be taking place."

For the forestry sector, the politicisation of the business groups was well noted with the patronage as Bob Hasan, and the business interests of the presidential family. The potential of these constituencies to influence policy to reflect their interests has been clear. But the examples and case studies presented here also show that the depoliticised 'amorphous mass' did consolidate their political will to create a policy win situation. In the ASC case the 'win' was clearly against the will of the more politically and economically powerful business representatives, a constituency which would have preferred policy which continued to ensure the maximum potential profits and returns on their investments.

One plausible conclusion is that as the New Oder matured, so the nature of the Indonesian polity became more attuned to the will of the people, not simply the political elite. For many years the NGO community were simultaneously encouraged and repressed and encouraged to to enhance the myth of democracy, by the then Minister for Environment and Population, Emil Salim, and simultaneously repressed by the ORMAS Law. However, corporatist channels also contained provisions for constituency representations to the political elite. The environmental NGOs took advantage of this situation to consolidate their place in the polity and exploit the corporatist channels to their own advantage. Failure of the government to close the corporatist channels to the NGOs, and the increasing political activity of the BINGOs could be read as a signal that the New Order government was been prepared to open political participation for selectively targeted groups, while closing down others.

In part, the political response resulted of the changing Indonesian population. More of the public were better educated, and better aware of the environmental consequences. As a result, social attitudes were changing towards environmental concerns. The emergence of a middle-class meant a greater percentage of the population could turn their attentions to issues such as the environment and forestry, as daily subsistence decreased. Likewise, the rural population was able to analyse government forestry and environmental policy. Consequently, a broader Indonesian constituency had become more aware and critical of the policies and responses of the government to environmental issues.

The argument that the New Order regime grew to be more attuned to the will of the people promotes an understanding of targeted pluralism as part of an evolutionary Indonesian polity. The Indonesian government, responding to social and economic changes nationally and internationally accepted the advocacy role of 
constituencies as part of the contemporary polity. Indeed, the polity was continually evolving. For example, the New Order changed as of Soeharto drew closer to the Islamic faithful. As Vatikiotis (p. 127) noted "for most of its twenty-five year rule the New Order government has demonstrated more suspicion than trust toward Islam." But with Soeharto's public support of Islamic constituencies in the late 1980s the Indonesian polity evolved to incorporate (limited) religious influence on secular politics. Likewise, the 'wins' of the environmental NGOs in this case study are an example of the evolutionary traits of the New Order.

However, the other plausible explanation for the inclusion of the environmental NGOs is simply that it is a matter of political practicality and as such their influence was temporary and opportunist. The government recognised its limitations in being able to protect the vast natural resources, and so delegated limited authority to the environmental community to act as watch-dogs. Even so, NGOs were acting for the government needed to be contained within the polity to stop any potential out-growth of real political power. But it also placed the onus government to compromise on certain issues if they were to continue to elicit the assistance of the NGOs. As a result, we did witness a situation whereby the NGOs were allowed to participate in the policy processes but did not denote but an unabashed love affair between the protagonists. Nonetheless, "on issues ranging from climate change, national park management and coastal preservation to environmental impact assessment of industrial projects, a productive partnership [was] emerging - both in terms of policy making and programme implementation. This is no mean feat in Indonesia" (Cohen, 1995). This opportunist argument promotes an understanding of the polity as one less affected by evolutionary influences: NGOs were more likely to be disbanded should their usefulness to the state end.

NGOs incorporation into the polity was valued also because the paramount objective of economic development. Or even more fundamentally, for President Soeharto to be seen to perpetuate economic development and ensure equitable redistribution of wealth. Resources had become a vital element of the overall economic development. The economic dependency on oil and oil related products was well documented, as was the shift to non-oil sectors after the crash of the early 1980's. The forestry sector became a pivotal income earner, although not ever reaching its full economic potential as a source of direct income for the state. But the emphasis on the (planned) economic potential of the sector resulted in (unplanned) events which pitted the government and the agents of the civil sector against each other. From the perspective of economic development, the government saw the areas of potential conflict or friction (such as socio-economic and socio-political stability), as being secured through the redistribution of national wealth. What was unplanned was been the people's dissatisfaction with the environmental degradation, and the fall in rural standards of living, in the pursuit of economic rewards by a few political and business elite. The inclusion of NGOs in development plans legitimated the view of New Order consideration of popular concerns. The environmental NGOs achieved positive policy outcomes by exploiting a form of targeted pluralism that was evident in the Indonesian polity.

\section{References}

A Bitter-sweet Existence. (1993, July 10). "Economic and Business Review Indonesia", Vol. 65, pp. 6-13. 
Aditjondro, G. (1988, November 10-16). "Scott's Investment: To Benefit or Destroy". The Times of Papua New Guinea.

Althusser, L. (1971). "Ideology and Ideological State Apparatuses (notes towards an investigation)". Lenin and Philosophy and Other Essays.

Amsyari, F. (1992). "Dasar-Dasar Dan Metoda Perencanaan Lingkungan Dalam Pembangunan Nasional". Jakarta: Widya Medika.

Barito's Rejection to Pay Rp.11.1b Fine Questioned. (1992). The Jakarta Post: Jakarta, Indonesia.

Bourchier, D. and Legge, J. (eds.). (1994). "Democracy in Indonesia 1950's and 1990's (Monash Papers on Southeast Asia No. 31)". Clayton: Monash University.

Bryant, R. (1994). "The Political Ecology of Resource Exploitation in South-East Asia". ASEASUK Annual Conference, March 28-30. London, UK: University of London.

Cohen, M. (1994, November 17). "Culture of Awareness". Far Eastern Economic Review, pp. 44-46.

Cohen, M. (1995, November 16). "Cautious Cooperation". Far Eastern Economic Review, pp. 67-70.

Concession Holders Urged to Help Nomadic Farmers. (1991, April 13) Jakarta, Indonesia: The Jakarta Post.

Cribb, R. (1988). "The Politics of Environmental Protection in Indonesia". Working Paper No. 48, Centre of Southeast Asian Studies, Monash University. Clayton, Australia.

Cullen, A. (1998). "Representing the Environment: Targeted Pluralism in the Forestry Sector of Indonesia". Griffith University, Australia.

Dauvergne, P. (1993-94). "The Politics of Deforestation in Indonesia". Pacific Affairs, Vol. 66, pp. 497-518.

Dixon, G. (1974). "Some Questions Regarding Timber Exploitation in East Kalimantan". Paper presented at the Centre of Southeast Asian Studies, Monash University. Melbourne, Australia.

Eccleston, B. (1994). "NGOs and the Environmental Politics of Deforestation in Asia". ASEASUK Conference. London, UK: University of London.

Foreign Forest Concessions Reminded of Mandatory Divestment. (1991, March 13). Jakarta, Indonesia: The Jakarta Post.

Hardjono, J. (1991). "The Dimensions of Indonesia's Environmental Problems". In J. Hardjono (ed.), Indonesia: Resources, Ecology, and Environment. Oxford, UK: Oxford University Press.

Hardoyo, H. (1992, February 28). "RI starts timber estates related to transmigration". Jakarta, Indonesia: The Jakarta Post.

Hasjurul Threatens Slash-and-burn Farmers in Sumatra. (1991, March 4). "Jakarta, Indonesia: The Jakarta Post.

Hurst, P. (1990). "Rainforest Politics: Ecological Destruction in South-East Asia". London, UK: Zed Books. Hutabarat, R. and Ganie, T. (1991). "Emil Salim: Law as Das Sollen". Voice of Nature, Vol. 94, pp. 6-7.

Jackson, K. (1978). "Bureaucratic Polity: A Theoretical Framework for the Analysis of Power and Communications in Indonesia". In P. L. K. D. Jackson (ed.), Political Power and Communications in Indonesia. Berkeley, USA: University of California Press.

Liddle, R. (1987). "Politics of Shared Growth: Some Indonesian Cases". Comparative Politics, Vol. 19, No. 1, pp. 127-146. 
MacIntyre, A. (1997). "Business and Politics in Indonesia". Sydney, Australia: Allen and Unwin.

McBeth, S. J. (1994, October 20). "Hazy Days". Far Eastern Economic Review, pp. 66-67.

Ministry of Forestry, Government of Indonesia, \& Food \& Agriculture Organisation. (1990). "Situation

and outlook of the forestry sector in Indonesia, Volume 4: social, environmental and institutional aspects". Jakarta, Indonesia: Director General of Forest Utilisation.

Number of Negligent Holders of Forest Concessions Declines. (1991, January 5). Jakarta, Indonesia: The Jakarta Post.

Pathay, M. and Aditjondro, G. (1987). Dampak Ekologis dan Sosial Penebanan Hutan Rawa dan Hutan Bakau oleh Pemegang HPH di Sawa Er, Asmat dan Babo, Monokwari, Irian Jaya. Yayasan Pengemangan Masyarakat Desa.

Pemerintah tak Berhak Kenakan Sanksi kepada PT Barito Pacific. (1991, August 13). Jakarta, Indonesia: Kompas

Poffenberger, M. (1990). "The Evolution of Forest Management Systems in Southeast Asia". In M. Poffenberger (ed.), Keepers of the Forest: Land Management Alternatives in Southeast Asia. West Hartwood, Australia: Kumarin Press.

Potter, D. (1994). "Democracy and the Environment in Asia". GECOU Working Paper No. 2. Milton Keynes, Open University

Prastowo, H. (1994, November). Interviewed by A. Cullen. Jakarta, Indonesian Forestry.

Ramansara, I. A. (1995, March). "Executive Secretary. Yayasan Pengembangan Prakarsa Wirausaha Di Irian Jaya". Jakarta, Indonesia.

Repetto, R. (1988). "The Forest for the Trees? Government Policies and the Misuse of Forest Resources". World Resources Institute.

Robison, R. (1986). "Indonesia: The Rise of Capital". Sydney, Australia: Allen and Unwin.

Salim, E. (1995, March). Interviewed by A. Cullen. Jakarta, Indonesian Forestry.

Schmitter, P. C. and Lehmbruch, G. (1979). "Trends toward Corporatist Intermediation". London, UK: Sage Publications.

SKEPHI. (1992). "The Annual Report of SKEPHI". Jakarta, Indonesia: SKEPHI - The Rainforest Information Centre.

Suharyanto, H. (1994, October 28). "The Machete Falls: Forestry Ministry May Axe 44 More Licences". Indonesia Business Weekly, No. 46.

Tree Felling on State Forest may Land Barito in Court. (1991, April 29). Jakarta, Indonesia: The Jakarta Post.

Vatikiotis, M. (1993). "Indonesian Politics Under Suharto". London, UK: Routledge.

Warning to Loggers.(1993, April 2). Jakarta, Indonesia: The Jakarta Post. 